\title{
Public Enterprise Reform: A Review of Policies and Privatisation in Bangladesh
}

\author{
Mehadi Mamun \\ Edith Cowan University \\ Sydney campus, 333 Kent Street, NSW-2000, Australia \\ E-mail: m.mamun@ecu.edu.au
}

Received: September 24, 2020 Accepted: October 29, 2020 Published: November 6, 2020

doi:10.5296/ber.v10i4.17728

URL: https://doi.org/10.5296/ber.v10i4.17728

\begin{abstract}
Bangladesh, as a developing country, has commenced public sector reforms and privatisation of state-owned enterprises following the actions and advice of different actors in different periods of its history. Though the policy mimic reforms in developed economies, this needs to be understood in the context of Bangladesh. This paper, therefore, reviews the country's industrial policies from its independence and international aid donors' assistance strategies to have a holistic look at the country's policy choices over the last four decades. The study finds that Bangladeshi governments have taken many steps towards privatisation since the mid-1970s on the advice of aid donors, however, the privatisation programmes have not brought the expected outcomes and there have no actual steps taken to uphold the interests of employees. The study has captured insights about the reform policies in Bangladesh and has several implications for policymakers as the country is still struggling to come out of poverty.
\end{abstract}

Keywords: Industrial policies, Aid donors, Privatisation, Bangladesh

\section{Introduction}

Public enterprises - state owned (more than 50\%) and controlled entities which have a separate legal identity, produce marketable goods and services, have an explicit or extractable budget, and are supposed to finance their operating costs from their own resources - are important financial and economic actors in Bangladesh as the contributions of public enterprises to the Gross Domestic Product (GDP), employment generation and revenue earning are still very significant to this developing country. Following independence in 1971, the Bangladesh government controlled over $86 \%$ of the total industrial assets in the country. In 2017, however, the public enterprises' fixed assets represented $24 \%$ of the country's total industrial assets as the Bangladesh government privatised a large array of state-owned 
enterprises (Sobhan, 2002; Ministry of finance, 2017). This paper employs document analysis research technique and examines a broad range of policy papers plus existing empirical evidence with the purpose of revealing how Bangladesh government's industrial policies towards privatisation have evolved over the years; how international institutional donors' policies have influenced the Bangladesh government's policy choices; how privatisation policies and processes have supported the privatisation programmes; and, how the privatised state-owned enterprises have performed over the years.

\section{Bangladesh Government's Policies and Approaches to Privatisation in different Periods}

The industrial policies in Bangladesh are in place since the country's independence. The policies adopted immediately after the independence were biased towards the management and creation of industries by the public sector. However, Bangladesh gradually liberalized its economy providing means for private investment and management in the economy. This paper analyses the industrial policies that have been formulated by various Bangladeshi governments since its independence.

\subsection{Industrial Investment Policy, 1973}

Due to the Liberation War and subsequent independence from Pakistan in 1971, many non-Bengali Pakistanis abandoned their industries. These were then taken over by the Sheikh Mujibur Rahman government under a nationalisation policy through Presidential Ordinance (PO) no. 27 of 1972. In accordance with this ordinance, the first industrial investment policy in Bangladesh was announced in January 1973. The nationalisation policy of Sheikh Mujibur Rahman's regime reflected the pro-socialist ideology of his party and government. The overall policy incentives were clearly aimed at fostering and maintaining public enterprises in large and medium scale industries, and limiting private sector activities to small industries (Sobhan, 2002; Ahmed, 2004). However, the policy was unsuccessful because the state-owned enterprises incurred significant losses after nationalisation. The following principal impediments were the cause for the failure of that nationalisation policy: (i) a shortage of efficient, trained managers to run the nationalised businesses, resulting in low productivity and poor performance; (ii) the need for enormous government subsidies to prop up the loss-making state-owned enterprises (SOEs); and, (iii) operational inefficiencies and administrative corruption (Ahmed, 2004; Chowdhury, 2008). At the same time that the public sector performed poorly, private investments tended to flinch. The factors that, allegedly, cramped private investments were as follows - (i) absence of an incentive structure to promote private investment; (ii) fear of further nationalisation haunted potential investors; (iii) underdeveloped infrastructure restricted potential investment; and, (iv) the weak legal system following the Liberation War was a disincentive to investors (Zohir, 1995; Sobhan, 2002).

\subsection{Revised Investment Policy, 1975}

After the fall of Sheikh Mujibur Rahman's government in August 1975, Ziaur Rahman's regime amended the Constitution of Bangladesh and replaced the word 'socialism' with 'economic and social justice'. Economic liberalisation was evident after that ideological shift 
(Humphrey, 1992). Industrial investment policy was revised in December 1975 and important policy changes were initiated to improve the investment climate. Some of the changes of that time were - (i) amendment of the constitution to allow denationalisation; (ii) revival of the stock market; (iii) shifting from tile fixed rate system of currency valuation to a managed floating exchange rate system; (iv) elimination of a ceiling on private investment; (v) relaxation of investment sanctioning procedures; and, (vi) introduction of a number of export promotion measures (Humphrey, 1992; Bhuyan \& Rashid, 1995).

The Industrial Investment Schedule (IIS) of 1976 was a major turning point in favour of privatisation, which allowed disinvestments of many discarded and nationalised factories through public tender, and the return of some factories to the original owners with financial liabilities attached. A total of 247 organisations were denationalised under the IIS (Chowdhury, 2008; Privatisation Commission, 2010a). However, that policy was not quite effective, because the factories were sick and faced closure in cases where the original owners could not arrange finance to settle the liabilities. Moreover, in the name of denationalisation and privatisation, some enterprises were sold at knockdown prices, and some were sold to those with little entrepreneurial background (Sobhan, 1990).

\subsection{New Industrial Policy (NIP), 1982}

The next significant move towards privatisation in Bangladesh occurred in 1982, when General Ershad came into power and announced the New Industrial Policy (NIP). The NIP was designed to bring changes in the industrial policy environment for soliciting Western support by adopting the World Bank and IMF's recommendations to promote private sector-led industrial growth (Chowdhury, 1990; Uddin \& Hopper, 2003). The principal objectives of the NIP were to: (i) encourage private sector-led industrial growth; (ii) substantially down-size the role of public sector by limiting its areas of responsibility; (iii) emphasise export oriented growth through bringing substantial changes to the structure of trade and industrial incentives, and export diversification; and, (iv) emphasise import liberalisation and rationalise the tariff structure (Chowdhury, 1990; Zohir, 1995).

Structural Adjustment Programmes (SAPs) were also introduced in Bangladesh in the mid-1980s. The formation of the Revised Industrial Policy of 1986 and the creation of the Board of Investment in 1989 were the two other important actions of the Ershad regime. The Revised Industrial Policy (RIP) of 1986 followed earlier moves towards deregulation and privatisation and gave more teeth to the on-going structural adjustment programmes. More export incentives were made available to the exporters, and more deregulation were carried on for importers. A number of import bans and quantitative restrictions were relaxed to support liberalisation of imports. Foreign private investment and export-oriented industries were given a greater emphasis and a one-stop investment service agency, the Board of Investments (BOI), was set up. A total of 125 organisations were denationalised during the NIP and RIP eras (Ahmed, 2004; Chowdhury, 2008; Privatisation Commission, 2010a).

\subsection{Industrial Policy, 1991}

After the change in government and re-democratisation in 1991, a new industrial policy was 
announced. In terms of philosophical underpinning, it appeared to be little different from its forerunner, but in terms of depth and width some discernible differences were evident. The whole industrial policy was premised on the philosophy of a market-based competitive economy. A number of relatively positive and far-reaching policy initiatives were undertaken to lure foreign and domestic investors, such as an end to permit requirements in connection with setting up industries, and removal of restrictive provisions for equity participation by foreigners.

For private sector investment, the sanctioning procedures were further simplified. Investment incentives, in particular for export-oriented and export-linkage industries, were expanded and made available to both local and foreign investors, without any discrimination. The repatriation of proceeds from the sale of shares, profits and dividends, tax exemption on royalties and capital gains from the transfer of shares were also assured. To assist in the establishment of export-oriented industries, more export processing zones were established. There were measures designed to liberalise foreign trade through rationalisation of the tariff structure and reduction of tariff and non-tariff barriers. In other words, the early 1990s experienced the most proactive phase of trade liberalisation (Ahmed, 2004; Momen, 2007).

Industrial Policy of 1991 was one of the major policies that drove private sector development in the 1990s. The gradual but definite shift towards privatisation policies continued throughout the 1990s. In 1991, the government formed an Inter-Ministerial Committee on privatisation to approve specific privatisation proposals from different administrative ministries. In 1993, the Privatisation Board was constituted through an administrative ordinance to better implement the privatisation programme, and 39 organisations were privatised after the establishment of the Privatisation Board (Privatisation Commission, 2010a, 2010b). The privatisation programme of Bangladesh between 1993 and 2000 was implemented under the guidelines of this Privatisation Board.

\subsection{Industrial Policy, 1999}

Another industrial policy was announced in 1999 following a change in government in 1996. The Industrial Policy of 1999 was a comprehensive policy and sought to give the private sector a dominant role in accelerating the pace of industrial development. The objectives outlined in the policy statement had a clear sense of direction. Its major objective was to have, within a decade, a sizeable industrial sector where manufacturing would account for at least $25 \%$ of GDP and $20 \%$ of the employed workforce. Among its other objectives were: (i) A focus on the role of the government as a facilitator in creating an enabling environment for expanding private investment; (ii) The attraction of foreign direct investment in both export and domestic market oriented industries; (iii) Encouragement for improving the competitive strength of import substituting industries for catering to a growing domestic market; (iv) Development of indigenous technology and expansion of raw materials production; and, (v) Rehabilitation of deserving sick industries.

The Industrial Policy of 1999 also focused on a process of industrialisation that was environmentally sound and consistent with the country's resource endowments. To uphold the principles of this Industrial Policy, Bangladesh government converted the Privatisation Board 
into a Commission in July 2000 with more financial and administrative power to intensify the privatisation programme drive through the enactment of the Privatisation Act 2000. The privatisation process in Bangladesh took concrete shape after the establishment of the Privatisation Commission.

\subsection{Industrial Policy, 2010}

After the change in government in 2008, a new industrial policy was announced in 2010 to raise industry sector's share in GDP to $35-45 \%$ by 2021 through industrialization, and to create a proactive and conducive environment in which private-sector industrial investors could operate without unnecessary bottlenecks, procrastination and undue interference. The principal objectives of the policy were to: (i) promote the private sector to lead the growth of industrial production and investment; (ii) place the role of the government as a facilitator in creating an enabling environment for expanding private investment and sustained economic growth; (iii) attract foreign direct investment in both export and domestic market oriented industries; (iv) ensure rapid growth of industrial employment by encouraging investment in labour incentive manufacturing industries; (v) generate female employment in higher skill categories through special emphasis on skill development; (vi) raise industrial productivity and to move progressively to higher value added products through skill and technology upgrading; and, (vii) ensure a process of industrialisation which is environmentally sound and consistent with the resource endowment of the economy.

\subsection{Industrial Policy, 2016}

The Industrial Policy of 2016 was framed as a supplementary policy paper but an important one, towards transforming Bangladesh into a middle-income country by 2021 through accelerating the pace of domestic industrialization and private sector led economic growth. The government identified the Small and Medium Enterprises (SMEs) as a priority sector and as the driving force for industrialisation. The Industrial Policy of 2016 was more exhaustive and detailed than the previous ones. It dealt with issues relating to changing global situation and the pattern of productivity. The policy also focused on green technology and products in the context of preserving the environment. Moreover, by including several new types of industries such as, high-tech, arts and crafts etc. the industrial categorization was expanded in the industrial policy of 2016.

\section{International Institutional Donor Policies on Privatisation in Bangladesh}

Bangladesh has relied on foreign aid as its major source of external finance since its independence in 1971 (see Table 1). When aid initially started to flow, it was primarily used for relief and repairing the damage incurred during the nine-month-long liberation war. In 1973, the first five-year development plan was launched. However, the inadequacy of domestic resources available to the economy persuaded the Bangladesh government to accept foreign aid in order to sustain some level of development activities. This ushered in a long era of aid dependence and the share of foreign aid in financing Annual Development Programme (ADP) still remained around 30\% in 2016 (Khatun, 2018). 
Table 1. Total foreign aid to Bangladesh from 1971-72 to 2016-17 FY

\begin{tabular}{|l|l|l|l|l|l|}
\hline $\begin{array}{l}\text { Financial } \\
\text { Year }\end{array}$ & $\begin{array}{l}\text { Total Foreign Aid } \\
\text { (in million US\$) }\end{array}$ & $\begin{array}{l}\text { Financial } \\
\text { Year }\end{array}$ & $\begin{array}{l}\text { Total Foreign Aid } \\
\text { (in million US\$) }\end{array}$ & $\begin{array}{l}\text { Financial } \\
\text { Year }\end{array}$ & $\begin{array}{l}\text { Total Foreign Aid } \\
\text { (in million US\$) }\end{array}$ \\
\hline $1971-72$ & 271 & $1987-88$ & 1640 & $2003-04$ & 1033 \\
\hline $1972-73$ & 551 & $1988-89$ & 1668 & $2004-05$ & 1507 \\
\hline $1973-74$ & 461 & $1989-90$ & 1810 & $2005-06$ & 1567 \\
\hline $1974-75$ & 901 & $1990-91$ & 1732 & $2006-07$ & 1630 \\
\hline $1975-76$ & 801 & $1991-92$ & 1611 & $2007-08$ & 2061 \\
\hline $1976-77$ & 535 & $1992-93$ & 1675 & $2008-09$ & 1847 \\
\hline $1977-78$ & 834 & $1993-94$ & 1559 & $2009-10$ & 2227 \\
\hline $1978-79$ & 1033 & $1994-95$ & 1739 & $2010-11$ & 1777 \\
\hline $1979-80$ & 1223 & $1995-96$ & 1585 & $2011-12$ & 2100 \\
\hline $1980-81$ & 1147 & $1996-97$ & 1481 & $2012-13$ & 2800 \\
\hline $1981-82$ & 1240 & $1997-98$ & 1251 & $2013-14$ & 3050 \\
\hline $1982-83$ & 1177 & $1998-99$ & 1536 & $2014-15$ & 3000 \\
\hline $1983-84$ & 1268 & $1999-00$ & 1588 & $2015-16$ & 3550 \\
\hline $1984-85$ & 1269 & $2000-01$ & 1369 & $2016-17$ & 3650 \\
\hline $1985-86$ & 1306 & $2001-02$ & 1442 & & \\
\hline $1986-87$ & 1596 & $2002-03$ & 1585 & & \\
\hline
\end{tabular}

Source: Ministry of Finance, Bangladesh (2003, 2012); Khatun (2018)

The dependence on foreign aid has given donors significant leverage over the country's policies. Major institutional donors, such as the World Bank and IMF have used this leverage to impose a variety of conditions on the Bangladesh governments, which are derived from neo-classical and capitalistic economic philosophy (Chowdhury, 1990; Uddin \& Hopper, 2001). A common condition tied to IMF and World Bank assistance in Bangladesh has been the privatisation of state-owned enterprises, and thus the privatisation programme started in the mid-1970s on the advice of aid donors (Sobhan, 1982; Uddin \& Hopper, 2003). To understand the principles and assistance strategies of the major international institutional donors in recent years, the following Country Assistance Strategies (CASs) are analysed:

\subsection{Bangladesh Country Assistance Strategy, 2001}

The World Bank jointly with three other development partners, such as the Asian Development Bank, the United Kingdom's Department for International Development, and the Government of Japan, prepared a Country Assistance Strategy (CAS) for Bangladesh. In doing that, the World Bank actively collaborated with the IMF on macroeconomic assessments. The Bangladesh Country Assistance Strategy (2001) focused on the following key strategic priorities: (1) accelerating private sector-led growth by helping to: (a) remove structural impediments, establish an environment conducive to private investment and provide advisory services related to privatisation, and (b) support private investments in energy, infrastructure, manufacturing and services; (2) helping to build stronger institutions and governance across development programs; (3) consolidating gains in human development and supporting initiatives to address development challenges in education, health, and nutrition; and, (4) implementing an integrated approach to rural development. 


\subsection{Bangladesh Country Assistance Strategy, 2006}

The Bangladesh Country Assistance Strategy (2006) was designed around three main themes:

(1) Improving the investment climate: The strategy was to build Bangladesh's economic strength by continuing to help maintain macroeconomic stability and accelerate its progress toward an open, market-based economy. The CAS (2006) focused on further trade liberalisation efforts by reducing non-tariff barriers and improving trade transport infrastructure.

(2) Empowering the poor: The CAS (2006) supported governance reforms and investments in health, education, sanitation, local government strengthening and safety net approaches.

(3) Core governance: The strategy also aimed to enhance accountability and transparency by strengthening 'core' governance institutions, such as the Public Service Commission, Securities and Exchange Commission, and Legal and Judicial System.

In this CAS period, the World Bank played a further role in assisting restructuring and privatisation, in cooperation with the IMF, through investment projects and policy-based lending. The CAS (2006) designed a programme of around $\$ 3$ billion of credits and grants from IDA (International Development Association), the World Bank's soft loan window, based on continued policy and implementation performance.

\subsection{Bangladesh Country Assistance Strategy, 2011}

The Bangladesh Country Assistance Strategy (2011) emphasized accelerated, sustainable and inclusive growth, underpinned by stronger governance at central and local levels. To accelerate growth, this CAS focused on massive infrastructure investment and a more conducive business environment to sustain recent levels of private sector growth. For more sustainable growth, this strategy included for the first time a priority of reducing vulnerability to the effects of climate change by increasing investments in water resources management, agricultural adaptation, environmental protection and disaster preparedness. To promote inclusive growth, this CAS emphasized long-standing support for human development and social welfare, with an increasing focus on education quality and skill building, and on lagging maternal health and nutrition outcomes. And, to strengthen governance, this CAS continued its support to enhance core governance and strengthen local government, as well as efforts to empower communities and build demand for good governance and accountability at the local level.

\subsection{Bangladesh - Country Partnership Framework, 2016}

Replacing the Country Assistance Strategy (CAS), the Country Partnership Framework (CPF) was the new central tool of the World Bank Group for reviewing and guiding the World Bank Group's country programs and gauging their effectiveness. It identified the key objectives and development results through which the World Bank Group intended to support Bangladesh in its efforts to end poverty and boost shared prosperity in a sustainable manner. The Country Partnership Framework (2016) focused on the following three areas: 
(1) Growth and competitiveness: The CPF's objectives were to: (i) enhance business environment and trade facilitation; (ii) increase power generation capacity; (iii) improve financial intermediation; (iv) improve delivery of basic services in urban areas; and, (v) improve transport connectivity. The World Bank Group allocated US\$ 130 million for the private sector development in FY2016-17.

(2) Social inclusion: The CPF's objectives were to - (i) improve equity in access of education; (ii) improve access to quality maternal and infant health services; (iii) improve social protection coverage for the poor; and, (iv) enhance rural income opportunities for the poor.

(3) Climate and environment management: The CPF's objectives were to - (i) improve water resource infrastructure for climate resilience; (ii) increase resilience of population to natural disasters in urban and coastal areas; and, (iii) increase adoption of sustainable agricultural practices.

Hence, one of the strategic priorities of all CASs $(2001,2006,2011)$ and CPF (2016) was an emphasis on a stable macroeconomic environment through following trade policy towards liberalisation and creating an enabling policy environment for private sector-led economic growth. In terms of creating an enabling environment for private sector-led economic growth, a policy agenda in all CASs and CPF was the restructure and/or privatisation of state-owned enterprises and the encouragement of private investment in Bangladesh.

\section{Privatisation Policy and Processes in Bangladesh}

Privatisation programmes in Bangladesh are implemented under the Privatisation Policy of 2007 and Privatisation Regulation of 2007. According to the Privatisation Policy of 2007, the objectives of the privatisation programme were to: (i) contribute to GDP and promote rapid economic growth by way of increased employment opportunities and productivity through the efficient allocation and utilisation of resources; (ii) transform non-performing state-owned enterprises into profitable units; (iii) attract foreign investment for improving managerial and operational efficiency at privatised SOEs, and transferring modern technology; (iv) earn revenue; and, (v) transfer resources from loss making enterprises to a profitable sector.

Privatisation Policy (2007) also promulgated the following general principles of privatisation: (i) to protect the interest of both workers and officials; (ii) to seek more employment through privatisation, assess the buyer's intentions regarding the development of the organisation, and give advice and support if needed; (iii) to take all necessary steps to avoid closure of viable factories; (iv) to take into account the current market value while selling the enterprises; (v) to protect the interests of the buyers while privatising an organisation; and, (vi) to maintain transparency, efficiency, confidentiality, and neutrality in the privatisation process.

The Privatisation Act of 2000 and the Privatisation Regulation of 2007 outlined the methods and processes of privatisation. Two methods were used in recent years. The first was the direct sale through international tender. A total of 27 SOEs were privatised by the Privatisation Commission through this method. The second method involved the sale of shares, with the Government off-loaded its equity as per the provisions of the Privatisation policy and the Memorandum and Articles of Association of the enterprise concerned. A total 
of 11 SOEs were privatised by the Privatisation Commission through this method (Privatisation Regulation, 2007; Privatisation Commission, 2010b, 2015).

A variety of procedural steps were followed to execute a privatisation programme in Bangladesh. A description of the privatisation process was: (i) first, the Bangladeshi Government identified SOEs for privatisation after discussion with different ministries and handed over the list to the Privatisation Commission for action; (ii) after receiving the list, the Privatisation Commission made a valuation of the SOEs concerned through the relevant agencies; (iii) before finalising a valuation, the Privatisation Commission discussed the findings with representatives of the relevant ministries; (iv) after finalising the valuation report, the Privatisation Commission opened an international tender to sell the SOEs or took the necessary steps to transfer ownership using the Stock Exchange; (v) if no acceptable bids were received, the Privatisation Commission invited fresh tenders; (vi) in the process of conducting any agreement in relation to a privatisation, the government took necessary steps to secure the safety of the related organisation's officers and workers; (vii) at the final stage, the Privatisation Commission submitted its recommendations to the government for approval before signing the necessary transfer documents; (viii) after receiving government approval, the Privatisation Commission concluded the transfer documents; (ix) money received from the privatisation of any SOE was deposited to the consolidated fund of the country, and was used to meet the outstanding loans and liabilities of the related enterprise; and, (x) after handing over SOEs, the Privatisation Commission followed up on post transfer progress.

The presence of the privatisation policy and structured procedures helped Bangladesh to accomplish its privatisation programme. Although the privatisation policy emphasised the protection of employee rights and interests, there was no actual step taken to enforce that protection in the privatisation process. In addition, the lack of a timeframe to complete the privatisation process, and a lack of an action plan on how to provide post-transfer support to the privatised SOEs and employees, constrained the privatisation process.

\section{Assessments of the privatisation programme in Bangladesh}

Inclusive study of the privatisation of state-owned enterprises in Bangladesh is relatively limited. The dominant interpretation of effectiveness has almost always emphasised the financial performance of privatised enterprises. The World Bank (2016) argued that privatisation in Bangladesh increased business efficiency, output and economic growth. Boubakri et al. (2008) conducted a study on the privatised enterprises in developing countries along with Bangladesh and concluded that privatisation brought major improvements to profitability and output in privatised enterprises. However, opponents pointed out that Bangladeshi state-owned enterprises followed a broad range of development goals, and the provision of jobs was more prioritised than profit maximisation (Sobhan, 2002; Momen, 2007). Hence, the effectiveness of privatisation has always been contested in Bangladesh. For example, Sen's 1997 study found that of the 205 industrial enterprises which were privatised since 1980, only 112 (54.6\%) were operational, 83 (40.5\%) had closed, and 10 (4.9\%) were not traceable. Among the 112 operational enterprises, only 5.6\% claimed that they were highly profitable, $33.8 \%$ said that they were profitable, $6.7 \%$ reported breaking even, $16.3 \%$ 
said they were making a loss and $43.6 \%$ reported high losses. Similarly, Dowlah (1998) found that of the 10 privatised enterprises, there was a decline in production by $23 \%$ after privatisation in five enterprises, while three lifted production by $91 \%$. Mamun's 2014 study found that employees at the state-owned factories felt secure in their jobs, while about $67 \%$ of the employees at the privatised factories felt insecure about their jobs. Islam (2015), thus, saw the spectre of de-nationalisation, which led many enterprises to the verge of collapse after privatisation.

\section{Conclusions}

This paper has examined several policy papers and existing empirical evidence with the purpose of revealing how Bangladesh government and institutional donors' policies towards privatisation have evolved over the years, how privatisation processes have supported the privatisation programme, and how the privatised enterprises have performed. The facts that successive Bangladeshi governments have taken many steps towards privatisation since the mid-1970s on the advice of aid donors and privatisation processes have taken concrete shape after the establishment of the institutional bodies, such as the Privatisation Board and the Privatisation Commission. Major international institutional donors' Country Assistance Strategies for Bangladesh have encouraged a policy environment that favours private sector-led economic growth. Their policy agenda for creating an enabling environment for private sector-led economic growth is to restructure and/or privatise state-owned enterprises. The existence of privatisation policies, processes and regulations have contributed to the privatisation programme in Bangladesh. Although privatisation policies have emphasised the protection of employee rights and interests, there have no actual steps taken to uphold the interests of employees. In some cases, authors have found that privatisation makes enterprises more successful, with benefits for consumers and companies. In other cases, privatisation has been seen as more harmful than helpful to employees as most of the employees at the privatised state-owned enterprises feel insecure in their jobs. International institutional donors continue to face questions regarding privatisation as a condition of their aid, though they see privatisation as a way to increase efficiency, investment and economic growth in Bangladesh. There are, however, the potential for further research to find out why about half of the privatised enterprises are shut down after privatisation, what factors determine post-privatization performance, and how to minimise any negative impacts of privatisation on employees. Since the consequences of privatisation of state-owned enterprises affect thousands across the country, it is very important to unveil its impact on employees, employers, investors, consumers, and the broader society to attain most out of the privatisation programmes in Bangladesh.

\section{References}

Ahmed, M. U. (2004). Privatization in Bangladesh. Geneva: International Labour Organization.

Bhuyan, A. R., \& Rashid M. A. (1995). Industrial policy in Bangladesh: a critical appraisal. Bangladesh Journal of Political Economy, 13(1), 345-371. 
Boubakri, N., Cosset, J. C., \& Guedhami, O. (2008). Privatisation in Developing Countries: Performance and Ownership Effects. Development Policy Review, 26(3), 275-308.

https://doi.org/10.1111/j.1467-7679.2008.00411.x

Chowdhury, J. A. (1990). Privatization in Bangladesh. Working Paper Series no. 92. The Hague: The Institute of Social Studies.

Chowdhury, M. A. S. (2008). An Overview on Privatization Program. Bangladesh: Privatization Commission.

Dowlah, C. F. (1998). Benefits of Privatization: Evidence from State-Owned Enterprises Privatized in Bangladesh During 1991-1996. Asia Pacific Development Journal, 5(2), 45-67.

Government of Bangladesh (1973). Industrial Investment Policy 1973. Ministry of Industries, Government of the People's Republic of Bangladesh.

Government of Bangladesh (1975). Revised Investment Policy 1975. Ministry of Industries, Government of the People's Republic of Bangladesh.

Government of Bangladesh (1982). New Industrial Policy (NIP) 1982. Ministry of Industries, Government of the People's Republic of Bangladesh.

Government of Bangladesh (1986). Revised Industrial Policy (RIP) 1986. Ministry of Industries, Government of the People's Republic of Bangladesh.

Government of Bangladesh (1991). Industrial Policy 1991. Ministry of Industries, Government of the People's Republic of Bangladesh.

Government of Bangladesh (1999). Industrial Policy 1999. Ministry of Industries, Government of the People's Republic of Bangladesh.

Government of Bangladesh (2010). Industrial Policy 2010. Ministry of Industries, Government of the People's Republic of Bangladesh.

Government of Bangladesh (2000). Privatization Act 2000. Government of the People's Republic of Bangladesh.

Government of Bangladesh (2007). Privatization Policy 2007. Cabinet Division, Government of the People's Republic of Bangladesh.

Government of Bangladesh (2016). Industrial Policy 2016. Ministry of Industries, Government of the People's Republic of Bangladesh.

Humphrey, C. N. (1992). Privatization in Bangladesh: Economic transition in a poor country. (Asian ed.). Bangladesh: University Press.

Islam, M. R. (2015). Privatising government owned enterprises. The Daily Star. [Online] Available: https://www.thedailystar.net/supplements/24th-anniversary-the-daily-star-part-1/pr ivatising-government-owned-enterprises-73282

Khatun, F. (2018). Can Bangladesh do without Foreign Aid?. Bangladesh: Centre for Policy 
Dialogue.

Mamun, M. (2014). The impact of privatization on workers' real wages and quality of working life in privatized enterprises in Bangladesh. Paper presented at the University of Technology Sydney, 13 November. Australia: Sydney.

Ministry of Finance (2003). Bangladesh Economic Review 2003. Finance Division, Ministry of Finance, Government of Bangladesh.

Ministry of Finance (2012). Bangladesh Economic Review 2012. Finance Division, Ministry of Finance, Government of Bangladesh.

Ministry of Finance (2017). Bangladesh Economic Review 2017. Finance Division, Ministry of Finance, Government of Bangladesh.

Momen, M. N. (2007). Implementation of Privatization Policy: Lessons from Bangladesh. The Innovation Journal: The Public Sector Innovation Journal, 12(2).

Privatisation Commission (2007). Privatization Regulation 2007. Privatization Commission, Bangladesh.

Privatisation Commission (2010a). Privatization in Bangladesh Opportunities and Potentials. Privatization Commission, Bangladesh.

Privatisation Commission (2010b). Study Report of Privatized SOEs. Privatization Commission, Bangladesh.

Privatisation Commission (2015). Achievement in the Privatization. Privatization Commission, Bangladesh.

Sen, B. (1997). Whither Privatisation: Results of an Exploratory Survey of Disinvested Industries in Bangladesh. Mimeo. Bangladesh: BIDS.

Sobhan, R. (1982). The Crisis of External Dependence-The Political Economy of Foreign Aid to Bangladesh. London: Zed Publishing.

Sobhan, R. (1990). Industrial Policy and Economic Stagnation in Bangladesh. Bangladesh Journal of Political Economy, 10(2), 114-137.

Sobhan, R. (2002). Privatisation in Bangladesh: An Agenda in Search of a Policy. Bangladesh: Centre for Policy Dialogue.

Uddin, S., \& Hopper, T. (2001). A Bangladeshi Soap Opera: Privatisation, Accounting, and Regimes of Control in a Less Developed Country. Accounting Organizations and Society, Oxford, 26(7/8), 643-672. https://doi.org/10.1016/S0361-3682(01)00019-8

Uddin, S., \& Hopper, T. (2003). Accounting for Privatisation in Bangladesh: Testing World Bank Claims. Critical Perspectives on Accounting, 14, 739-774.

https://doi.org/10.1016/S1045-2354(02)00188-0

World Bank. (2001). Bangladesh Country Assistance Strategy 2001. Washington DC: World 
Bank.

World Bank. (2006). Bangladesh Country Assistance Strategy 2006. Washington DC: World Bank.

World Bank. (2011). Bangladesh Country Assistance Strategy 2011. Washington DC: World Bank.

World Bank. (2016). Bangladesh - Country Partnership Framework 2016. Washington DC: World Bank.

Zohir, S. C. (1995). An assessment of industrial policy: what policies are we talking about?. Bangladesh Journal of Political Economy, 13(1), 372-412.

\section{Copyright Disclaimer}

Copyright for this article is retained by the author(s), with first publication rights granted to the journal.

This is an open-access article distributed under the terms and conditions of the Creative Commons Attribution license (http://creativecommons.org/licenses/by/4.0/). 